\title{
Thyroid Ima Artery
}

National Cancer Institute

\section{Source}

National Cancer Institute. Thyroid Ima Artery. NCI Thesaurus. Code C53023.

An artery that can arise from the innominate (brachiocephalic) artery, aortic arch, internal

mammary artery, right common carotid artery, or the subclavian artery to supply the lower portion of the thyroid gland. 